\title{
First report the genus Dendrochernes Beier, 1932 (Pseudoscorpiones: Chernetidae) from China, with description of a new species
}

\section{Первая находка можноскорпионов рода Dendrochernes Beier, 1932 (Pseudoscorpiones: Chernetidae) в Китае, с описанием нового вида}

\author{
Zhizhong Gao', Feng Zhang ${ }^{2 *}$ \\ Жииконг ЖКао ${ }^{1}$, Фенг ЖКанг ${ }^{*}$
}

\footnotetext{
${ }^{1}$ Department of Biology, Wutai Mountain Institute of Resource and Environment, Xinzhou Teachers University, Xinzhou, Shanxi 034000, P. R. China. E-mail: gaozhizhong1987@126.com

2 The Key Laboratory of Zoological Systematics and Application, College of Life Sciences, Hebei University, Baoding, Hebei 071002, P. R. China. E-mail: dudu06042001@163.com

*Corresponding author
}

KEY WORDS: Arachnida, taxonomy, fauna, pseudoscorpion, morphology.

КЛЮЧЕВЫЕ СЛОВА: паукообразные, таксономия, фауна, ложноскорпион, морфология.

ABSTRACT. The chernetid genus Dendrochernes Beier, 1932, belonging to the subfamily Chernetinae, is reported from China for the first time. Dendrochernes mahnerti sp.n. from Xinjiang Uygur Autonomous Region, China, is described and illustrated.

How to cite this article: Gao Zhizhong, Zhang Feng. 2020. First report the genus Dendrochernes Beier, 1932 (Pseudoscorpiones: Chernetidae) from China, with description of a new species // Arthropoda Selecta. Vol.29. No.2. P.229-234. doi: 10.15298/arthsel. 29.2.07

РЕЗЮМЕ. Род ложноскорпионов Dendrochernes Beier, 1932 из подсемейства Chernetinae впервые отмечен в фауне Китая. Дано иллюстрированное описание нового вида Dendrochernes mahnerti sp.n. из Синьцзян-Уйгурского автономного региона Китая species .

\section{Introduction}

The Chernetidae Menge is the most speciose family in Pseudoscorpiones and is composed of over 650 species in more than 110 genera, but only 10 genera and 16 species have been reported from China [Schawaller, 1995; Harvey, 2013; Gao et al., 2017; Gao, Zhang, 2019]. The chernetid genus Dendrochernes was erected by Beier in 1932, and at present comprises only four known species: the type species $D$. cyrneus (L. Koch, 1873 ) is widespread in central Asia (Pakistan, Kazakhstan and Kyrgyzstan), north Africa and Europe; while the remaining three species occur in north America: $D$. crassus Hoff, 1956 and D. morosus (Banks, 1895) (Canada, USA), D. instabilis (Chamberlin, 1934) (USA) [Harvey, 2013].

Kanas Lake, located in a valley in the Altai Mountains in the Burqin County of Altay Prefecture, north- western China, is China's deepest freshwater alpine lake, with a high biodiversity [Sulayman et al., 2010; Abliz et al., 2014]. It borders with the country of Kazakhstan, Mongolia and Russia. While examining pseudoscorpion specimens collected from Xinjiang, two chernetid specimens presenting the generic characters of Dendrochernes were examined: eye spots lacking or indistinct; tergites divided except the last one and finely to moderately granulate; setae of body and palps broadened and thickened, denticulate and short, never strongly clavate; rallum with 4 (but occasionally 3 ) blades; palps stout, finely to moderately granulate; accessory teeth of chelal fingers numerous; tactile seta $s t$ of movable finger nearer to $s b$ than to $t$; fixed finger with tactile seta ist at the level of or very little distal to the level of est; tarsus IV with a tactile seta located distal to the midpoint of the tarsus, being 0.6 to 0.7 of the length of the tarsus from the proximal margin of the segment; the spermatheca of the female with two long, slender tubules, of uniform diameter throughout, greatly coiled, and without a terminal enlargement or bulb [Chamberlin, 1934; Hoff, 1956]. This is the first record of this genus in China, and we describe and illustrate the new species under the name Dendrochernes mahnerti sp.n.

\section{Material and Methods}

The specimens referred to here are preserved and examined in 75\% alcohol and deposited in the Museum of Hebei University (MHBU), Baoding City, China. Photographs were obtained using a Leica M205a stereomicroscope equipped with a Leica DFC425 Camera and LAS software (Ver. 4.0), which was also used for drawings (with a drawing tube) and measurements. Detailed examination was carried out with an Olympus BX53 general optical microscope. Temporary 


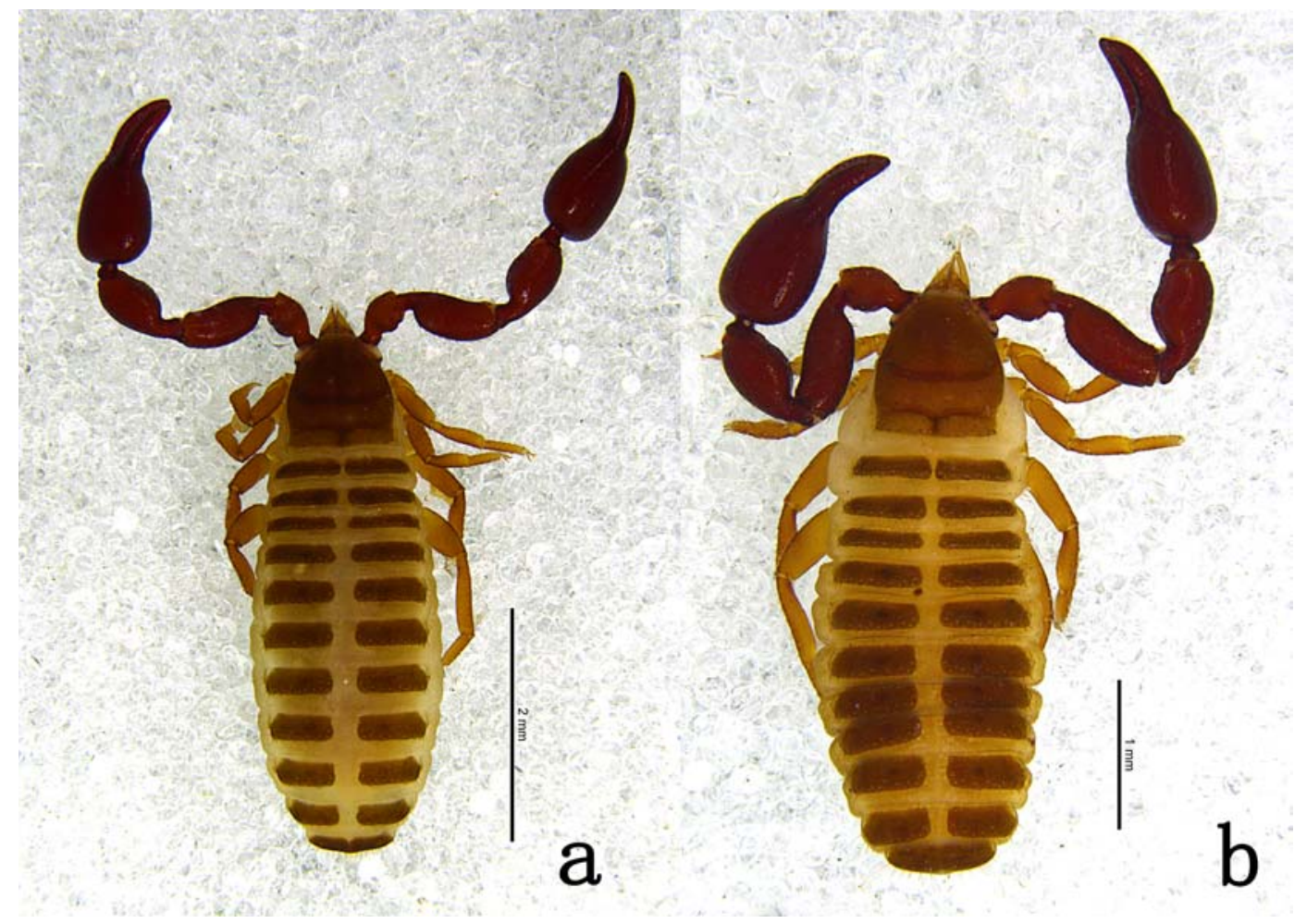

Fig. 1. Dendrochernes mahnerti sp.n., a - female holotype habitus, dorsal view; b - female paratype habitus, dorsal view.

Рис. 1. Dendrochernes mahnerti sp.n., a - внешний вид самки, голотип, дорсально; b - внешний вид самки, паратип, дорсально.

slide mounts were made in glycerol. Detailed examination was carried out with an Olympus BX53 general optical microscope. Temporary slide mounts were made in glycerol.

Terminology and measurements mostly follow Chamberlin [1931], with some minor modifications to the terminology of the trichobothria [Harvey, 1992], chelicera [Judson, 2007]. The chela and chelal hand are measured in lateral view and all measurements are given in mm unless noted otherwise.

The following abbreviations are used in the text for the chelal trichobothria: $b$ - basal; $s b$ - sub-basal; st - subterminal; $t$ - terminal; $i b$ - interior basal; is $b$ - interior sub-basal; ist - interior sub-terminal; it - interior terminal; $e b$ - exterior basal; esb - exterior sub-basal; est exterior sub-terminal; et - exterior terminal.

\section{Taxonomy}

Family Chernetidae Menge, 1855 Subfamily Chernetinae Menge, 1855

\section{Genus Dendrochernes Beier, 1932}

Dendrochernes Beier, 1932: 172-173.

Pachycheirus Chamberlin, 1934: 125-126

TYPE SPECIES:

Dendrochernes: Chernes cyrneus L. Koch, 1873, by original designation.

Pachycheirus: Pachycheirus instabilis Chamberlin, 1934, by original designation.

\section{Dendrochernes mahnerti sp.n.}

Figs. 1-3.

MATERIAL EXAMINED: Holotype 9 (Ps.-MHBU-XJ060825), China: Xinjiang Uygur Autonomous Region, Burqin County, Kanas National Nature Reserve $\left[48^{\circ} 44^{\prime} \mathrm{N}, 87^{\circ} 01^{\prime} E\right]$, a.s.1. $1456 \mathrm{~m}, 25$ August 2006, under tree bark, Feng Zhang leg. Paratype: 1 (Ps.MHBU-XJ06082501), same data as holotype.

ETYMOLOGY. The specific name is a patronym in memory of Dr. Volker Mahnert, a famous zoologist and arachnologist, who has made significant contribution and leaves behind an outstanding scientific legacy on pseudoscorpions.

DIAGNOSIS. Slender pedipalps (chela with pedicel 2.63-2.75 times as long as broad), spermathecae with two very long, coiled tubules, without terminal expanded; tactile seta $s t$ of movable chelal finger closer to $s b$ than to $t$; rallum with 3 or 4 blades; tarsus of leg IV with a tactile seta in terminal third of the segment.

The new species is most similar to D. cyrneus, which is also distributed in central Asia [Harvey, 2013]. However, $D$. mahnerti sp.n. differs from $D$. cyrneus by having a more slender palps, especially the chela (e.g. pedipalpal femur 2.63-2.71 times vs 2.40 times, patella 2.18-2.23 times $v s$ $1.80-2.10$ times; hand with pedicel 1.56-1.59 times $v s 1.30$ 1.40 times; chela with pedicel 2.63-2.75 times vs 1.80-2.00 times) [Beier, 1963]. In contrast with the illustrations provided by Callaini [1986] and Dashdamirov [2005], D. mahnerti sp.n. has longer and thicker tubles in the spermatheca, and also with less accessory teeth on chelal fingers (accessory teeth all along the chelal fingers in D. cyrneus) [Dashdamirov, 2005]. The new species can be distinguished from 

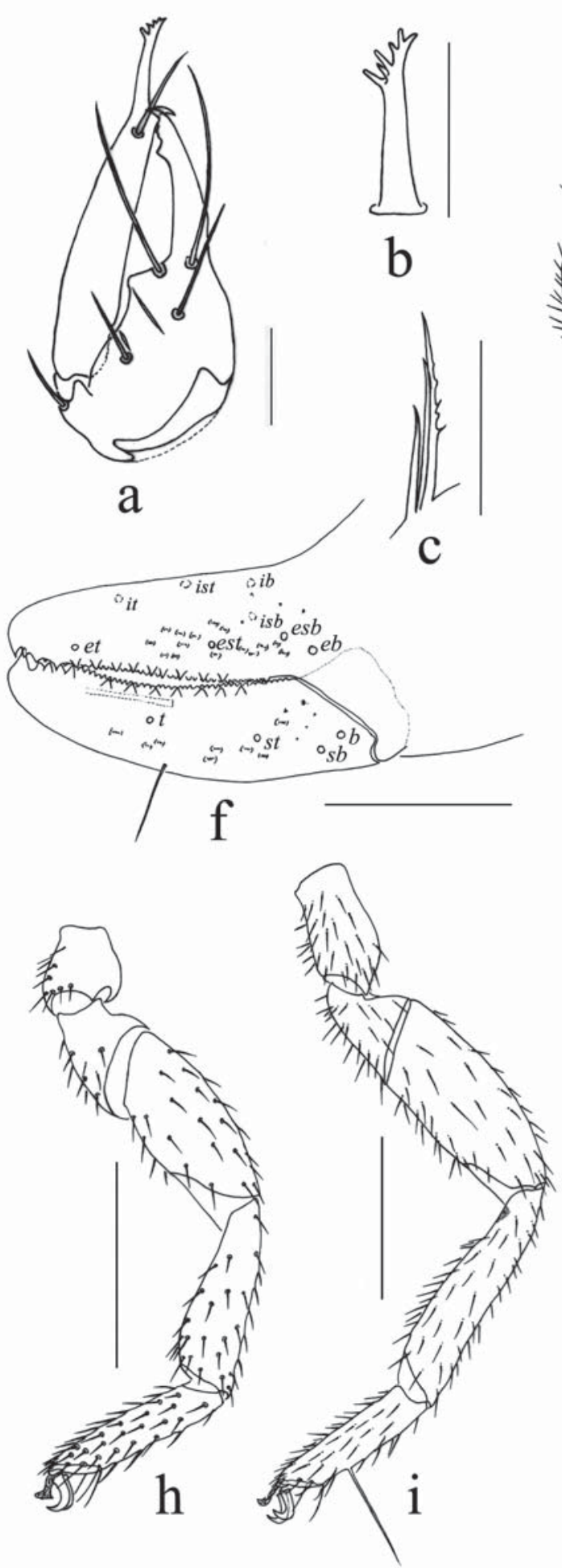
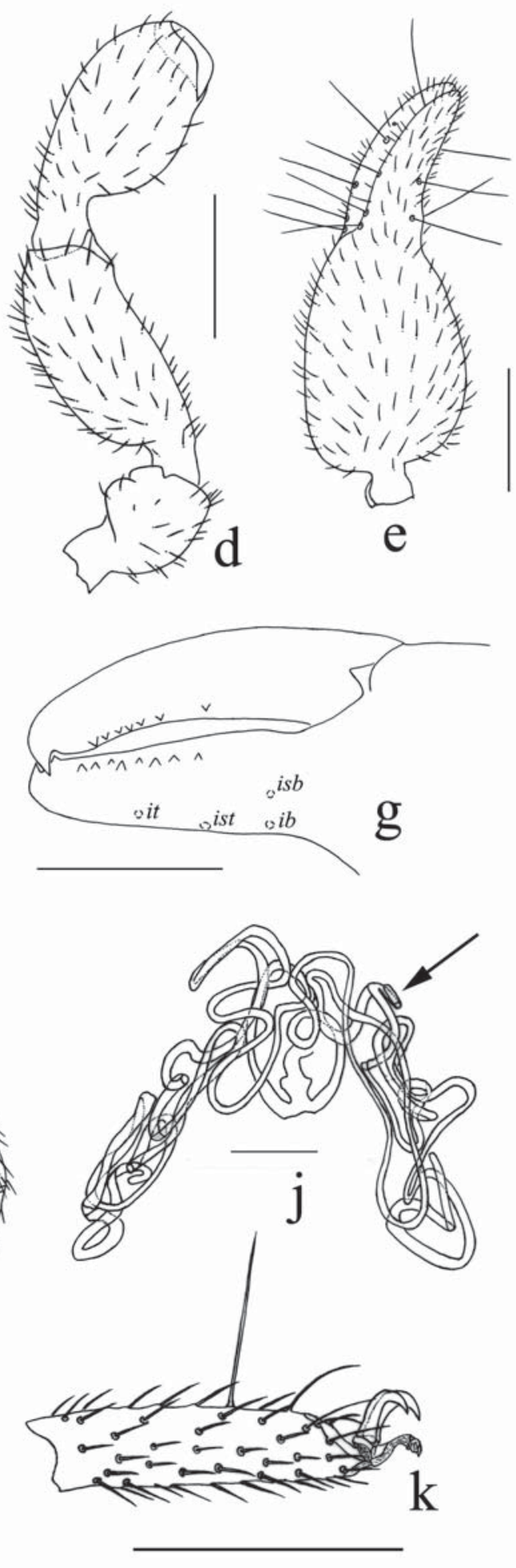

Fig. 2. Dendrochernes mahnerti sp.n., holotype female: a — chelicera, dorsal view; b — galea, dorsal view; c - rallum; d — left palp, dorsal view; e - chela, dorsal view; f - lateral view of right chelal fingers, showing chaetotaxy; $\mathrm{g}$ - interior view of right chelal fingers, showing accessory teeth; $h$ - leg I, lateral view; $\mathrm{i}$ - leg IV, lateral view; $\mathrm{j}$ - spermatheca; $\mathrm{k}$ - tarsus of leg IV, lateral view. Scale bars: $0.1 \mathrm{~mm}(\mathrm{a}-\mathrm{c}, \mathrm{j}) ; 0.4 \mathrm{~mm}(\mathrm{f}-\mathrm{g}, \mathrm{k}) ; 0.5 \mathrm{~mm}(\mathrm{~d}-\mathrm{e}, \mathrm{h}-\mathrm{i})$.

Рис. 2. Dendrochernes mahnerti sp.n., самка, голотип: a - хелицера, дорсально; b - галея, дорсально; с — раллум; $\mathrm{d}$ - левая пальпа, дорсально; е - хела, дорсально; f - пальцы правой хелы, латерально, показана хетотаксия; g - пальцы правой хелы, вид изнутри, показаны дополнительные зубцы; $\mathrm{h}$ - нога I, латерально; i — нога IV, латерально; j - сперматека; $\mathrm{k}$ - лапка ноги IV, латерально. Масштаб: 0,1 мм (a-c, j); 0,4 мм (f-g, k); 0,5 мм (d-e, h-i). 

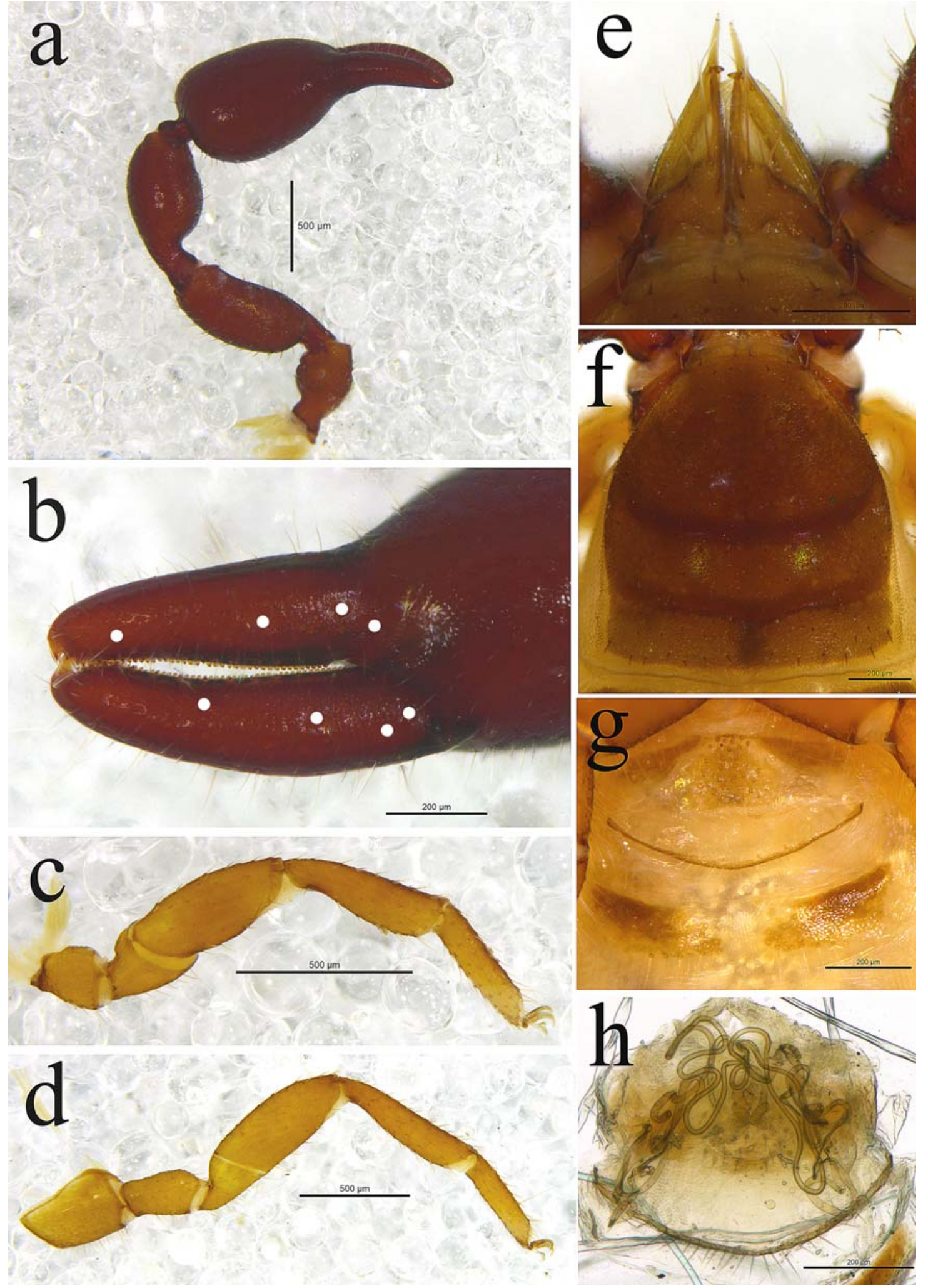

Fig. 3. Dendrochernes mahnerti sp.n., holotype female: a - left palp, dorsal view; b - chela, dorsal view; c - leg I, lateral view; d leg IV, lateral view; e - chelicerae, dorsal view; $\mathrm{f}$ - carapace, dorsal view; $\mathrm{g}$ - genital operculum, ventral view; $\mathrm{h}$ - spermatheca, dorsal view. Scale bars: $0.2 \mathrm{~mm}(\mathrm{~b}, \mathrm{e}-\mathrm{h}) ; 0.5 \mathrm{~mm}(\mathrm{a}, \mathrm{c}-\mathrm{d})$.

Рис. 3. Dendrochernes mahnerti sp.n., самка, голотип: a - левая пальпа, дорсально; b - хела, дорсально; с - нога I, латерально; d - нога IV, латерально; е - хелицеры, дорсально; f - карапакс, дорсально; g — половая крышка, вентрально; $\mathrm{h}$ сперматека, дорсально. Масштаб: 0,2 мм (b, e-h); 0,5 мм (a, c-d). 
D. instabilis and D. crassus by the slender chela (chela of $D$. instabilis 2.10-2.20 times, of D. crassus 2.39 times, of $D$. mahnerti sp.n. 2.63-2.75 times) [Chamberlin, 1934; Hoff, 1956]. D. mahnerti sp.n. shares the character of slender chela, while the new species with a more slender pedipalpal femur (2.63-2.71 times vs 2.37-2.46 times) [Hoff, 1947]. In addition, in consideration of the geographic distribution, all other congeners except D. cyrneus (which occurs in Europe) are distributed in North American, the new species extend a more broad distribution of the genus to central Asia.

DESCRIPTION. Color mostly reddish brown, carapace, legs brown, tergites and palps darker, remaining parts (sternites and pleural membranes) light yellowish brown. Most setae slightly apically denticulate.

Carapace. Surface evenly granular. Slightly longer than broad (1.07-1.17 times), eyespots indistinct, with two regularly granular transverse furrows, both of them very distinct, the subbasal one slightly nearer to the posterior margin than to median furrow, a longitudinal shallow groove in metazone. With about 110 setae, including 6 on anterior margin and $12-13$ on posterior margin. All setae short and apically dentate.

Abdomen. All tergites widely divided except the last one. Lateral keels absent; weakly scale-shaped sculpture. Half-tergites with about 8-11 setae, tergite VI with 13-16 setae (include 2 long tactile setae), anus with 2 simple and acuminate setae. Manducatory process with 5 setae. All sternites distinctly divided except VI, weakly scaly sculptured, setae simple and acuminate, chaetotaxy (IV-XI): 6(5)6: 13-13(16): 15(16)-15: 14(17)-14(15): 11(15)-12(15): 11(15)-11(16): 9(11)-10(11): 12 (include 4 long tactile setae): 2 (simple and acuminate setae). Coxae of pedipalps scale-shaped sculpture, with about 21 , coxae I with about 15, II 20, III about 25 setae, IV numerous setae. Anterior genital operculum with about 31-32 simple and acuminate setae, 21-22 setae in a row along the posterior margin of the posterior operculum.

Genitalia. Structure of female genitalia as illustrated (Fig. 3g). Spermatheca (Fig. 2j) with 2 long tubules, both of them without distinct terminal enlargements or bulbs.

Chelicera (Fig. 2a-c). With weakly scale-shaped sculpture. Five setae in basal part, all of them simple and acuminate; with 2 lyrifissures on the dorsal face of palm; fixed fingers with a few different sized teeth in the end. Movable finger with a seta in midway of terminal of finger; serrula exterior with 23-24 lamellae. Rallum usually with 4 blades, but occasionally with 3 , anterior blade slightly denticulate (Fig. 2c). Galea with 6 short branches (Fig. 2b).

Pedipalps (Fig. 3d-e). Palp slender, most segments normally granulate; except for chelal fingers, which are finely gaping; setae acuminate and weakly apically dentate; without tactile setae on femur, patella or hand; trochanter with distinct rounded dorsal hump; proportions (based on two specimens): trochanter $1.41-1.70$ times as long as broad; femur 2.63-2.71 times as long as broad; patella 2.18-2.23 times as long as broad; chela with pedicel $2.63-2.75$ times as long as broad, chela without pedicel $2.45-2.54$ times as long as broad, hand with pedicel 1.56-1.59 times, without pedicel 1.37-1.41 times, as long as broad. Movable finger $0.77-0.78$ times as long as hand with pedicel, and 0.88 times without pedicel. fixed finger with 36-37 teeth, 11-12 acuminate accessory teeth on lateral side, $7-8$ accessory teeth on interior side; movable finger with 40-44 teeth, 10-11 acuminate accessory teeth on lateral side, 6-7 accessory teeth on interior side; nodus ramosus closer to $t$ than to $s t$. Trichobo- thrial pattern as illustrated in Fig. 2f-g: distance between finger tip and it slightly longer than that between ist and isb. Tactile seta $s t$ of movable chelal finger closer to $s b$ than to $t$.

Venom apparatus only present in moveable chelal fingers, venom duct slender, extend over trichobothrium $t$ in movable fingers.

Leg I (Fig. 2h). Typical facies, with numerous terminal slightly denticulate and acuminate setae, tactile setae absent, weakly scale-like sculpture, claws simple; proportions: trochanter 1.00-1.31 times; femur 1.45-1.47 times; patella 2.30 2.35 times; tibia 3.43-3.54 times; tarsus 4.20-4.56 times as long as deep. Subterminal tarsal seta simple, acuminate and curved, arolium shorter than claws.

Leg IV (Fig. 2i, k). Surface weakly scale-like sculptured; tibia and tarsus with numerous terminal slightly denticulate and acuminate setae, trochanter 1.68-1.71 times; femur+ patella 3.23-3.48 times; tibia 4.44-4.53 times; tarsus 3.753.83 times as long as deep. An acute tactile seta in terminal third of tarsus ( $\mathrm{TS}=0.65-0.67$ ) and almost the half long as tarsus; arolia undivided and shorter than the simple and large claws, subterminal seta simple, acuminate and curved.

Measurements (length/width or depth for leg I and IV, based on two specimens).

Total length 3.80-4.35; Carapace 0.96-0.98/0.84-0.90. Palp: trochanter 0.51-0.52/0.30-0.37; femur 0.92/0.34-0.35; patella $0.87 / 0.39-0.40$; chela with pedicel $1.62-1.63 / 0.59-$ 0.62 ; length of chela without pedicel $1.50-1.52$; length of hand with pedicel $0.94-0.97$, without pedicel $0.83-0.85$; length of movable finger $0.73-0.75$. Leg I (length/depth): trochanter 0.17-0.21/0.16-0.17; femur 0.28-0.29/0.19-0.20; patella $0.46-0.48 / 0.20$; tibia $0.46-0.48 / 0.13-0.14$; tarsus $0.41-0.42 / 0.09-0.10$. Leg IV: trochanter $0.36-0.37 / 0.21-0.22$; femur+patella $0.84-0.87 / 0.25-0.26$; tibia $0.68-0.71 / 0.15-0.16$; tarsus $0.45-0.46 / 0.12$; length of tactile seta $0.23-0.25$.

DISTRIBUTION. China (Xinjiang).

REMARKS. Both chelicerae of the holotype and paratype were examined in different orientations to obtain an "allround-view" of each rallum. Although most had four blades, which is typical of the genus (e.g. Beier, 1963), the left rallum of the holotype consisted of only three blades (Fig. 2c).

The right tubule of the spermatheca in the holotype possesses a short branch indicated by the arrow in Fig. $2 \mathrm{j}$, which is unusual, we subsequently dissected the spermatheca of the paratype and there is no any modification on both tubules, so we prefer to think that the presence of a short branch on the right spermatheca of the holotype is an anomaly.

D. cyrneus, the type species, is widespread across Europe and Asia [Harvey, 2013], with vast literatures citations. It is difficult to identify a specimen to species level only based on immature individuals which little diagnostic characteristic can be used, for instance, extraordinarily dark coloring of the carapace, the palps and the tergites is absent in juveniles [Redikorzev, 1928]. The record from Kyrgyzstan are based on only a deutonymph [Dashdamirov, Schawaller, 1995], although it is possible that D. cyrneus distributed in Kyrgyzstan on the view of zoogeographic distribution, but the record is still unreliable.

Acknowledgements. We are grateful to Dr. Mark S. Harvey (Western Australian Museum, Perth, Australia) for assistance in the identification of the specimens. Thanks are also given to the late Dr. Volker Mahnert (Muséum d'Histoire naturelle, Geneva) for helping us to improve an earlier version of this manuscript in 2012, we express our sincere 
gratitude to him for his valuable assistance over many years. This work was supported by the National Natural Science Foundation of China (No. 31872198), by Shanxi Applied Basic Research Project (201801D221283), by Scientific and Technological Innovation Programs of Higher Education Institutions in Shanxi (2019L0823) and also by the Scientific Research Project of Xinzhou Teachers University (2018KY01).

Disclosure Statement. No potential conflict of interest was reported by the authors.

\section{References}

Abliz O., Nurmammat G., Tursun A., Hajim M. 2014. Community characteristics of soil mesofauna in Kanas Natural Reserve, Xinjiang // Journal of Arid Land Resources and Environment. Vol.28. No.2. P.68-73.

Beier M. 1932. Pseudoscorpionidea II. Subord. C. Cheliferinea // Tierreich. Lfg.58. S.1-294.

Beier M. 1963. Ordnung Pseudoscorpionidea (Afterskorpione) // Bestimmungsbücher zur Bodenfauna Europas. Berlin: Akademie-Verlag. Bd.1. S.1-313.

Callaini G. 1986. Appunti su alcune specie italiane della famiglia Chernetidae Menge (Arachnida, Pseudoscorpionida). Notulae Chernetologicae XV // Bollettino del Museo Civico di Storia Naturale, Verona Vol.11. P.379-401.

Chamberlin J.C. 1934. On two species of false scorpions collected by birds in Montana, with notes on the genus Dinocheirus (Arachnida - Chelonethida) // Pan-Pacific Entomologist. Vol.10. P.125-132.

Dashdamirov S. 2005. Pseudoscorpions from the mountains of northern Pakistan (Arachnida: Pseudoscorpiones) // Arthropoda Selecta. Vol.13 (for 2004). No.4. P.225-261.

Dashdamirov S., Schawaller W. 1995. Pseudoscorpions from Middle Asia, Part 4 (Arachnida: Pseudoscorpiones) // Stuttgarter Beiträge zur Naturkunde. Ser.A. Bd.522. P.1-24.
Gao Z., Zhang F., Harvey M.S. 2017. A modified definition of the genus Haplochernes (Pseudoscorpiones: Chernetidae), with a new species from Hainan Island // Journal of Arachnology. Vol.45. No.1. P.112-122. https://doi.org/10.1636/JoA-S-16042.1

Gao Z., Zhang F. 2019. First record of the genus Orochernes (Pseudoscorpiones: Chernetidae) from China, with description of a new species // Zootaxa. Vol.4612. No.1. P.126-132. https://doi.org/10.11646/zootaxa.4612.1.9

Harvey M.S. 1992. The phylogeny and classification of the Pseudoscorpionida (Chelicerata: Arachnida) // Invertebrate Taxonomy. Vol.6. P.1373-1435. https://doi.org/10.1071/IT9921373

Harvey M.S. 2013. Pseudoscorpions of the World. Version 3.0. Western Australian Museum, Perth. Available from: http:// museum.wa.gov.au/catalogues-beta/pseudoscorpions (accessed 8 August 2019)

Hoff C.C. 1956. Pseudoscorpions of the family Chernetidae from New Mexico // American Museum Novitates. No.1800. P.166.

Judson M.L.I. 2007. A new and endangered species of the pseudoscorpion genus Lagynochthonius from a cave in Vietnam, with notes on chelal morphology and the composition of the Tyrannochthoniini (Arachnida, Chelonethi, Chthoniidae) // Zootaxa. Vol.1627. No.1. P.53-68. https://doi.org/10.11646/zootaxa.1627.1.4

Redikorzev V. 1928. Beiträge zur Kenntnis der Pseudoscorpionenfauna Bulgariens // Mitteilungen aus dem Königl. Naturwissenschaftlichen Institut in Sofia. Bd.1. S.118-141.

Schawaller W. 1995. Review of the pseudoscorpion fauna of China (Arachnida: Pseudoscorpionida) // Revue suisse de Zoologie. T.102. Fasc.4. P.1045-1064.

Sulayman M., Gong Z.S., Abdurehim A., Eziz R., Anwar D. 2010. Bryoflora and Species Diversity in Kanas Natural Reserve, Xinjiang // Journal of Wuhan Botanical Research. Vol.28. No.4. P.424-430.

Responsible editor K.G. Mikhailov 